Article

\title{
X-ray Structures of Precursors of Styrylpyridine-Derivatives Used to Obtain 4-((E)-2-(Pyridin-2-yl)vinyl)benzamido- TEMPO: Synthesis and Characterization
}

\section{Guillermo Soriano-Moro *, María Judith Percino, Ana Laura Sánchez, Víctor Manuel Chapela, Margarita Cerón and María Eugenia Castro}

Laboratorio de Polímeros, Centro de Química, Instituto de Ciencias, Benemérita Universidad Autónoma de Puebla (BUAP), Complejo de Ciencias, ICUAP, Edif. 103H, 22 Sur y San Claudio, C.P. 72570 Puebla, Puebla, Mexico

* Author to whom correspondence should be addressed; E-Mail: jesus.soriano@correo.buap.mx; Tel. +52-222-2295500 (ext. 7299); Fax: +52-222-2295551.

Academic Editor: Derek J. McPhee

Received: 25 February 2015 / Accepted: 25 March 2015 / Published: 2 April 2015

\begin{abstract}
The synthesis and characterization of the precursor isomers trans-4-(2-(pyridin2-yl)vinylbenzaldehyde (I), trans-4-(2-(pyridin-4-yl)vinylbenzaldehyde (II), trans-4-(2(pyridin-2-yl)vinylbenzoic acid (III) and (E)-4-(2-(pydridin-4-yl)vinylbenzoic acid (IV) are reported. These compounds were prepared in order to obtain trans-4-((E)-2-(pyridin-2yl)vinyl)benzamide-TEMPO (V). Compounds I and II were obtained by using a Knoevenagel reaction in the absence of a condensing agent and solvent. Oxidation of the aldehyde group using the Jones reagent afforded the corresponding acid forms III and IV. A condensation reaction with 4-amino-TEMPO using oxalyl chloride/ $\mathrm{DMF} / \mathrm{CH}_{2} \mathrm{Cl}_{2}$ provided the 4-((E)-2-(pyridin-2-yl)vinyl)benzamide-TEMPO. Single crystals of compounds I, II and III were obtained and characterized by X-ray diffraction. Compound I belongs to space group $P 2{ }_{1} / c, a=12.6674(19) \AA, b=7.2173(11) \AA, c=11.5877(14) \AA$, $\beta=97.203(13)^{\circ}$ and the asymmetric unit was $Z=4$, whereas compound II was in the space group $P 2{ }_{1}$, with $a=3.85728(9) \AA, b=10.62375(19) \AA, c=12.8625(2) \AA, \beta=91.722(2)^{\circ}$ and the asymmetric unit was $Z=2$. Compound III crystallized as single colorless needle crystals, belonging to the monoclinic system with space group $P 2{ }_{1}$, with $Z=2$, with $a=3.89359(7) \AA, b=17.7014(3) \AA, c=8.04530(12) \AA, \beta=94.4030(16)^{\circ}$. All compounds were completely characterized by IR, ${ }^{1} \mathrm{H}-\mathrm{NMR}$, EI-MS and UV-Vis.
\end{abstract}


Keywords: X-ray structures; single crystal; styrylpyridine derivatives; 4-((E)-2-(pyridin-2yl)vinyl)benzamido-TEMPO; methylpyridines; $p$-terephthaldehyde

\section{Introduction}

Since the first stable radical compound was synthesized in 1961 [1] a series of stable radical structures, such as nitroxyl, phenoxyl, and hydrazyl have been successfully synthesized. These compounds are stable radical compounds that have an electron spin in spite of being organic materials [2]. Nitrogen heterocyclic nitroxides and their diamagnetic derivatives (sterically hindered amine and hydroxylamine) are known as low-molecular-weight multifunctional antioxidants that can participate in one-electron redox processes. Nitroxides have attenuated oxidative damage in various experimental models, including cultured cells [3], brain injury [4], lipid peroxidation in liver microsomes [5], post-ischemic reperfusion injury in isolated organs [6], and exhibit ionizing irradiation damage in rats and mice [7]. Recent investigations have focused on the synthesis of several molecules modified with nitroxides [8-11]. For example, 2,2,6,6-tetramethylpiperidine 1-oxyl (TEMPO) and its derivatives have been successfully used in modification processes to graft polar species such as $-\mathrm{OH}$ or ester groups onto polymers [12]. Also, molecules bearing nitroxides covalently linked to fluorophore have been used as fluorescence spin-label [13-16] or nuclear-localizing redox probes [17].

In recent years, dyes have been widely used as photoinitiators of free radical polymerization and as fluorescence probes for spectroscopy studies in monitoring specific chemical properties of the medium in which they are incorporated. Therefore, these compounds permit measurements of medium polarity or degree of cure by measuring the changes in the emission intensity or value of the shift in the emission maximum. Also, these dyes have found applications in the development of organic and molecular-based magnetic materials [18]. Currently, there is great interest in applying molecular-based magnetic materials to the development of spin systems with various properties, particularly with respect to photoand heat-responsive spin systems. The development of novel spin systems has led to the discovery of conjugated organic spin systems which respond to outside stimuli, such as light, heat, pressure and electrons, etc. Attempts have been made to develop spin systems with multiple properties [19].

Distyrylbenzenes and related fluorophores have found widespread applications in optical display devices [20-25], as nonlinear optical materials [26-28], two-photon absorbers [29-31], and for sensing purposes [32,33]. The combination of electron-pair donating and electron-pair accepting (EPA) substituents on a $\pi$-system can lead to an efficient internal charge transfer, resulting in bathochromic shifts of the electronic spectra, dual fluorescence [34-37], and efficient two-photon absorption. These properties depend on the length and nature of the $\pi$-system and the strength and position of donor and acceptor groups [38]. In addition, the presence of electron withdrawing groups in the $\pi$-system, such as replacing benzene rings with electron deficient heterocycles like pyridine [39-42], has been a successful route to increase the electron affinity. The introduction of a nitrogen atom into the ring noticeably affects the photophysical and photochemical behavior of stilbene. Our work has focused on model compounds with trans conformation distyrylbenzene (DSB) linked with pyridine moieties (styrylpyridines) which had been obtained without the need for catalyst and solvent [43-51]. We have also conducted studies to 
understand their effects on the optics and electronic properties from a theoretical perspective [52]. Xray studies of model compounds showed that although the molecules were planar, they did not exhibit a total delocalization of their electrons throughout the whole molecule, i.e., they did not exhibit complete aromaticity. X-ray results reported that the conformation of the double bond was trans. Therefore, using conjugated compounds such as styrylpyridine attached to TEMPO could be widely used to prolong the lifetime of coatings, bulk polymers, thin films, as well applications to label polymers or as a measure of molecular mass by IR and UV spectroscopy.

In this paper, we report the preparation of precursors to obtain low molecular weight styrylpyridine derivatives bearing TEMPO, and their structures obtained by X-ray crystallography analysis, together with their complete characterization. Our goal is to use these compounds as labels of polymers to measure the polymer molecular mass. The precursors are interesting because of the presence of groups such as $-\mathrm{COH}$ and $-\mathrm{COOH}$, that allow different absorption properties.

\section{Results and Discussion}

Several approaches for the preparation for methylpyridines with aromatic aldehydes have recently been carried out. Solvent-free methods at temperatures of $120-140{ }^{\circ} \mathrm{C}$ were successfully used to synthesize different styrylpyridines and $\alpha, \beta$-acrylonitriles as well as intermediates formed in the condensation reaction of methylpyridines and aromatic aldehyde compounds $[53,54]$. The procedure to obtain the compounds I and II allowed us to control the reaction of just one aldehyde group from terephthalaldehyde during the condensation reaction with the methyl group that formed the double bond. The behavior of this reaction is attributed to the control of the reaction temperature rather than to the molar ratios of reactants, because when the reaction was carried out at higher temperature, compounds such as 1,4-bis(2,2-diphenylethenyl)benzene or 1,4-bis(4,4-diphenylethenyl)benzene were formed instead of I and II. Our results also showed that the position of the methyl group on the pyridine ring affected its reactivity. Compounds III and IV were prepared with Jones oxidation conditions allowing their preparation in a convenient and safe procedure. The modest yield was attributed to the effect of the nitrogen atom in the ortho position, affording lower solubility to compound IV. In addition, we obtained III as the pure acid by recrystallization with $\mathrm{CH}_{3} \mathrm{OH}: \mathrm{DMF}(80: 20)$.

\subsection{Characterization}

Characterization from IR, ${ }^{1} \mathrm{H}-\mathrm{NMR}$, and EI spectra of $\mathbf{I}-\mathbf{V}$ showed characteristic features indicating that the precursors with the isomers structures of trans-(E)-4-(2-(pyridin-2-yl)vinyl- and trans-(E)-4-(2(pyridin-4-yl)vinyl- contained the functional group $-\mathrm{COH},-\mathrm{COOH}$. The ORTEP structures of I-III including the atomic numbering scheme are shown in Figure 1. Selected crystal data, structure solution and refinement for isomers I, II and III are listed in Table 1. Table 2 gives selected bond lengths with estimated standard deviations also for all three compounds. 


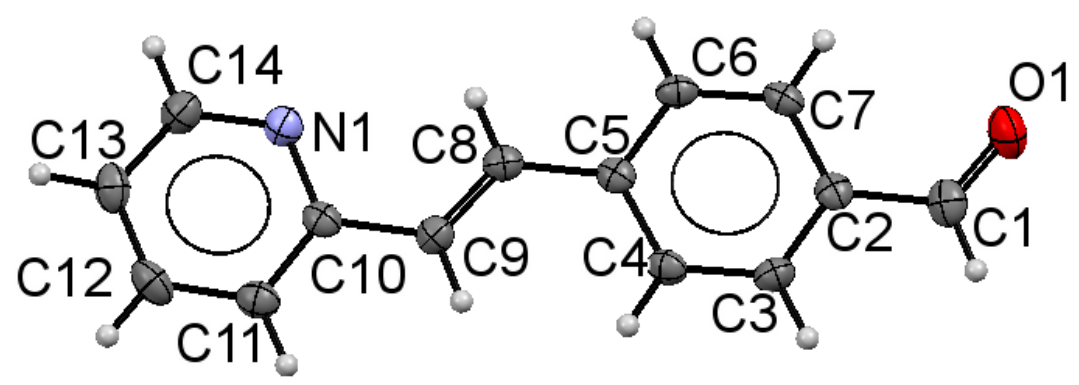

I

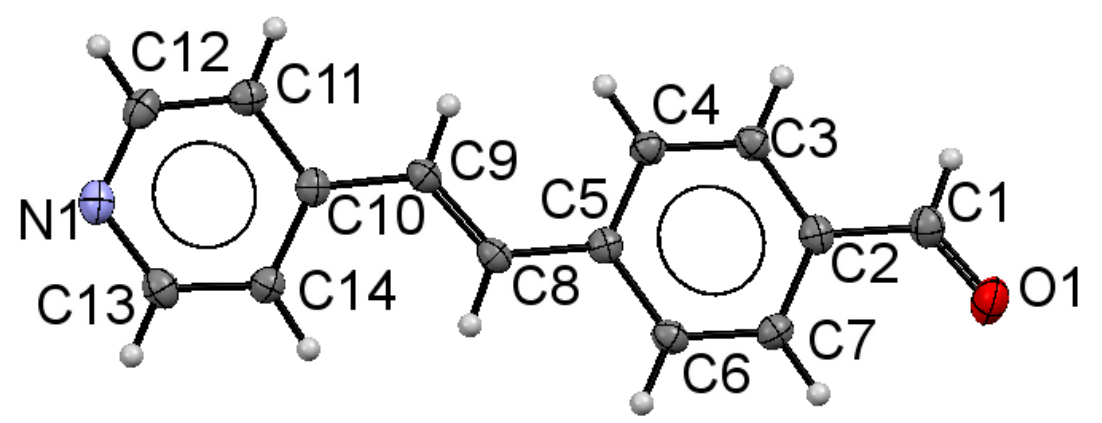

II

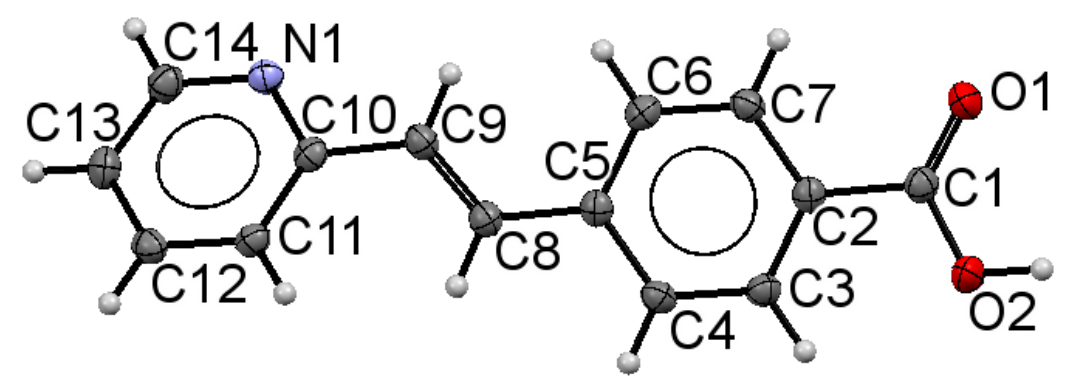

III

Figure 1. Molecular structures of I, II and III. The displacement ellipsoids are drawn at the $50 \%$ probability level and $\mathrm{H}$ atoms are shown as small spheres of arbitrary radii.

Table 1. Crystallography Data for I, II and III compounds.

\begin{tabular}{cccc}
\hline & I & II & III \\
\hline Empirical formula & $\mathrm{C}_{14} \mathrm{H}_{11} \mathrm{NO}$ & $\mathrm{C}_{14} \mathrm{H}_{11} \mathrm{NO}$ & $\mathrm{C}_{14} \mathrm{H}_{11} \mathrm{NO}_{2}$ \\
Crystal system & monoclinic & monoclinic & monoclinic \\
Color, Habit & colorless irregular block & yellow, block & Needle, colorless \\
Formula weight & 209.24 & 209.24 & 225.24 \\
Space group & $P{ }_{1} / c$ & $P 2_{1}$ & $P 2_{1}$ \\
$T(K)$ & $110(2)$ & $100(2)$ & $110(2)$ \\
$A(\AA)$ & $12.6674(19)$ & $3.85728(9)$ & $3.89359(7)$ \\
$b(\AA)$ & $7.2173(11)$ & $10.62375(19)$ & $17.7014(3)$ \\
$c(\AA)$ & $11.5877(14)$ & $12.8625(2)$ & $8.04530(12)$ \\
$\alpha\left(^{\circ}\right)$ & 90.00 & 90.00 & 90.00 \\
$\beta\left(^{\circ}\right)$ & $97.203(13)$ & $91.722(2)$ & $94.4030(16)$ \\
$\gamma\left({ }^{\circ}\right)$ & 90.00 & 90.00 & 90.00 \\
$V\left(\AA^{3}\right)$ & $1051.0(3)$ & $526.852(18)$ & $552.862(16)$ \\
\hline
\end{tabular}


Table 1. Cont.

\begin{tabular}{cccc}
\hline & I & II & III \\
\hline$Z$ & 4 & 2 & 2 \\
$\mathrm{Dc}\left(\mathrm{g} \mathrm{cm}^{-3}\right)$ & 1.322 & 1.319 & 1.353 \\
$F(000)$ & 592 & 220 & 440 \\
$\mu\left(\mathrm{mm}^{-1}\right)$ & 0.663 & 0.662 & 0.740 \\
$\lambda(\AA)$ & 1.5418 & 1.5418 & 1.5418 \\
Crystal size $\left(\mathrm{mm}^{3}\right)$ & $0.25 \times 0.10 \times 0.03$ & $0.39 \times 0.28 \times 0.22$ & $0.24 \times 0.09 \times 0.06$ \\
$2 \theta$ max $\left(^{\circ}\right)$ & 143.8 & 143.8 & 143.8 \\
No of reflections & 6697 & 6136 & 7517 \\
$\mathrm{~N}^{\circ}$ of unique reflections, I $>2 \sigma(\mathrm{I})$ & 1933 & 2037 & 2165 \\
$\mathrm{R}_{1}(\mathrm{I}>2 \sigma(\mathrm{I})), \mathrm{R}_{1}($ all $)$ & $6.08,8.29$ & $3.03,3.05$ & $2.75,2.79$ \\
$\mathrm{wR}_{2}(\mathrm{I}>2 \sigma(\mathrm{I})), \mathrm{wR} \mathrm{R}_{2}($ all $)$ & $17.16,18.39$ & $8.63,8.65$ & $7.43,7.48$ \\
goodness-of-fit & 1.169 & 1.085 & 1.054 \\
Largest diff peak and hole $\left(\mathrm{e} \AA^{-3}\right)$ & 0.22 and -0.27 & 0.21 and -0.21 & 0.21 and -0.16 \\
\hline
\end{tabular}

Table 2. Bond lengths $(\AA)$ for compounds I, II and III.

\begin{tabular}{cccc}
\hline & I & II & III \\
\hline $\mathrm{C}(1)-\mathrm{O}(1)$ & $1.212(4)$ & $1.212(2)$ & $1.219(2)$ \\
$\mathrm{C}(1)-\mathrm{C}(2)$ & $1.470(4)$ & $1.477(2)$ & $1.493(2)$ \\
$\mathrm{C}(2)-\mathrm{C}(3)$ & $1.391(4)$ & $1.392(2)$ & $1.392(2)$ \\
$\mathrm{C}(2)-\mathrm{C}(7)$ & $1.398(4)$ & $1.394(2)$ & $1.398(3)$ \\
$\mathrm{C}(4)-\mathrm{C}(5)$ & $1.400(4)$ & $1.402(2)$ & $1.399(3)$ \\
$\mathrm{C}(5)-\mathrm{C}(6)$ & $1.406(4)$ & $1.403(2)$ & $1.401(2)$ \\
$\mathrm{C}(5)-\mathrm{C}(8)$ & $1.462(4)$ & $1.470(2)$ & $1.466(2)$ \\
$\mathrm{C}(6)-\mathrm{C}(7)$ & $1.376(4)$ & $1.386(2)$ & $1.383(3)$ \\
$\mathrm{C}(8)-\mathrm{C}(9)$ & $1.331(4)$ & $1.331(2)$ & $1.335(3)$ \\
$\mathrm{C}(9)-\mathrm{C}(10)$ & $1.469(4)$ & $1.469(2)$ & $1.470(2)$ \\
$\mathrm{C}(10)-\mathrm{C}(11)$ & $1.399(4)$ & $1.393(2)$ & $1.397(3)$ \\
$\mathrm{C}(11)-\mathrm{C}(12)$ & $1.382(5)$ & $1.391(2)$ & $1.381(3)$ \\
$\mathrm{C}(13)-\mathrm{C}(14)$ & $1.395(5)$ & $1.388(2)$ & $1.386(3)$ \\
$\mathrm{C}(12)-\mathrm{C}(13)$ & $1.370(5)$ & & $1.386(3)$ \\
$\mathrm{C}(10)-\mathrm{N}(1)$ & $1.351(4)$ & & $1.352(2)$ \\
$\mathrm{C}(14)-\mathrm{N}(1)$ & $1.330(4)$ & & $1.335(2)$ \\
$\mathrm{C}(1)-\mathrm{O}(2)$ & & & $1.317(2)$ \\
$\mathrm{C}(10)-\mathrm{C}(14)$ & & $1.397(2)$ & \\
$\mathrm{C}(12)-\mathrm{N}(1)$ & & $1.338(2)$ & \\
$\mathrm{C}(13)-\mathrm{N}(1)$ & & $1.343(2)$ & \\
\hline
\end{tabular}

The molecular structures for compounds I and II were ordered. The 4-phenylcarbaldehyde moiety is located trans to the pyridine ring in the molecule in relation to the double bond. The bond lengths for

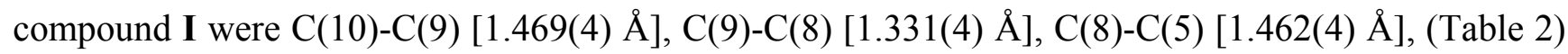
while the corresponding bonds lengths for the compound II were 1.469(2) $\AA$ 1.331(2) $\AA$, 1.470(2) $\AA$. These values indicated that the compounds contained a double bond in conjugation with an aromatic ring, $\left(\mathrm{Csp}^{2}=\mathrm{Cs} p^{2}\right.$; trans of $1.32 \AA$ conjugation; $\mathrm{Cs} p^{2}-\mathrm{Car}(\mathrm{C}=\mathrm{C}-\mathrm{Car}$ conjugated at $1.47 \AA)$ as well as a 
delocalization of the $\pi$ electrons $\mathrm{Car--C}$ ar in the phenyl ring of $1.387 \AA$, in the two six-membered rings through the $\mathrm{C}(8)-\mathrm{C}(9)$ bond. Similar distances were observed for the 2-styrylpyridine derivatives and were slightly different than the reported values [55]. Bond lengths C(1)-O(1) for I and II were of the equal value, 1.212(4) $\AA$ for aldehyde $\left(\mathrm{Cs} p^{2}=\mathrm{O}\right.$ in $\mathrm{Car}-\mathrm{C}=\mathrm{O}$ of $\left.1.221 \AA\right)$ [55]. Also, the results showed that structures I and II were almost planar molecules, with the pyridyl ring and 4-phenylcarbaldehyde group being coplanar with the double bond (Tables 3 and 4). For $\mathbf{I}$, the torsion angles between the atoms $\mathrm{C}(8)-\mathrm{C}(9)-\mathrm{C}(10)-\mathrm{N}(1)$ were $0.4(5)^{\circ}, \mathrm{C}(4)-\mathrm{C}(5)-\mathrm{C}(8)-\mathrm{C}(9)$ of $1.0(5)^{\circ}$ and between $\mathrm{O}(1)-\mathrm{C}(1)-\mathrm{C}(2)-\mathrm{C}(3)$ were $-172.1(3)^{\circ}$. Compound II showed torsion angles between $\mathrm{C}(8)-\mathrm{C}(9)-\mathrm{C}(10)-\mathrm{C}(14)$ of $1.2(3)^{\circ}, \mathrm{C}(4)$ $\mathrm{C}(5)-\mathrm{C}(8)-\mathrm{C}(9)$ of $-4.6(2)^{\circ}$, and between $\mathrm{O}(1)-\mathrm{C}(1)-\mathrm{C}(2)-\mathrm{C}(3)$ of $179.57(16)^{\circ}$. The partial $\pi$ character of the $\mathrm{C}(9)-\mathrm{C}(8), \mathrm{C}(10)-\mathrm{C}(9)$ and $\mathrm{C}(8)-\mathrm{C}(5)$ bonds (Table 2) helps to explain the aromatic planar nature of the molecules. The difference between both compounds is in the molecular crystal packing (Figure 2). For I, the molecular packing does not present regular hydrogen bonding between molecules. However, the packing motif showed a non-classical herringbone packing with a weak $\pi-\pi$ overlap between neighboring molecules. For compound $\mathbf{I}$, the distances between the co-facial $\pi$ - $\pi$ overlap interaction $\mathrm{C} / \pi \ldots \mathrm{C} / \pi$ was $3.381 \AA$, between $\mathrm{CH}(\text { py })^{\cdots} \mathrm{C}(\mathrm{Ar})(2.843 \AA)$ and $\mathrm{C}(\mathrm{Ar}) \cdots \mathrm{CH}(\mathrm{py})(2.865 \AA)$. Within each stack, however, the molecules are translated (slipped) along the short axis, thus minimizing the $\pi$-overlapping between them. A similar interaction arises for compound II between $\mathrm{CH}(\mathrm{COH}) \cdots \mathrm{N}(\mathrm{Py})$ of $2.683 \AA$, and $\mathrm{C}(\mathrm{CO}){ }^{\cdots} \mathrm{CH}(\mathrm{Py}) 2.615 \AA$, but II did not present short contact interactions such as $\mathrm{CH} / \pi \cdots-\mathrm{CH} / \pi$.

Table 3. Bond angles $\left(^{\circ}\right)$ for compounds I, II and III.

\begin{tabular}{cccc}
\hline & I & II & III \\
\hline $\mathrm{O}(1)-\mathrm{C}(1)-\mathrm{C}(2)$ & $124.5(3)$ & $124.68(16)$ & $122.50(17)$ \\
$\mathrm{C}(3)-\mathrm{C}(2)-\mathrm{C}(1)$ & $119.0(3)$ & $118.97(15)$ & $121.85(17)$ \\
$\mathrm{C}(7)-\mathrm{C}(2)-\mathrm{C}(1)$ & $122.1(3)$ & $121.11(15)$ & $119.15(16)$ \\
$\mathrm{C}(4)-\mathrm{C}(5)-\mathrm{C}(8)$ & $122.8(3)$ & $122.25(14)$ & $119.27(16)$ \\
$\mathrm{C}(6)-\mathrm{C}(5)-\mathrm{C}(8)$ & $119.4(3)$ & $118.76(13)$ & $122.46(16)$ \\
$\mathrm{C}(9)-\mathrm{C}(8)-\mathrm{C}(5)$ & $126.4(3)$ & $126.24(14)$ & $125.65(17)$ \\
$\mathrm{C}(8)-\mathrm{C}(9)-\mathrm{C}(10)$ & $124.7(3)$ & $125.54(14)$ & $124.62(17)$ \\
$\mathrm{C}(11)-\mathrm{C}(10)-\mathrm{C}(9)$ & $119.9(3)$ & $119.68(14)$ & $123.49(16)$ \\
$\mathrm{N}(1)-\mathrm{C}(14)-\mathrm{C}(13)$ & $124.0(3)$ & $124.18(15)$ & $122.86(19)$ \\
$\mathrm{N}(1)-\mathrm{C}(10)-\mathrm{C}(11)$ & $122.0(3)$ & & $120.93(17)$ \\
$\mathrm{N}(1)-\mathrm{C}(10)-\mathrm{C}(9)$ & $118.1(3)$ & & $115.58(16)$ \\
$\mathrm{C}(13)-\mathrm{C}(12)-\mathrm{C}(11)$ & $119.4(3)$ & & $119.76(18)$ \\
$\mathrm{C}(12)-\mathrm{C}(13)-\mathrm{C}(14)$ & $118.1(3)$ & & $118.04(18)$ \\
$\mathrm{C}(14)-\mathrm{N}(1)-\mathrm{C}(10)$ & $117.5(3)$ & & $119.27(16)$ \\
$\mathrm{C}(11)-\mathrm{C}(10)-\mathrm{C}(14)$ & & $116.77(14)$ & \\
$\mathrm{C}(14)-\mathrm{C}(10)-\mathrm{C}(9)$ & & $123.54(15)$ & \\
$\mathrm{N}(1)-\mathrm{C}(12)-\mathrm{C}(11)$ & & $124.19(16)$ & \\
$\mathrm{C}(13)-\mathrm{C}(14)-\mathrm{C}(10)$ & & $119.44(15)$ & \\
$\mathrm{C}(12)-\mathrm{N}(1)-\mathrm{C}(13)$ & & $115.91(14)$ & \\
$\mathrm{C}(1)-\mathrm{O}(2)-\mathrm{H}(2)$ & & & $114.4(18)$ \\
$\mathrm{O}(2)-\mathrm{C}(1)-\mathrm{C}(2)$ & & & $124.11(17)$ \\
$\mathrm{O}(1)-\mathrm{C}(1)-\mathrm{O}(2)$ & & & \\
\hline
\end{tabular}


Table 4. Torsion angles $\left({ }^{\circ}\right)$ for compounds I, II and III.

\begin{tabular}{cccc}
\hline & I & II & III \\
\hline $\mathrm{O}(1)-\mathrm{C}(1)-\mathrm{C}(2)-\mathrm{C}(3)$ & $-172.1(3)$ & $179.57(16)$ & $170.38(19)$ \\
$\mathrm{O}(1)-\mathrm{C}(1)-\mathrm{C}(2)-\mathrm{C}(7)$ & $7.5(5)$ & $-1.9(3)$ & $-8.9(3)$ \\
$\mathrm{C}(4)-\mathrm{C}(5)-\mathrm{C}(8)-\mathrm{C}(9)$ & $1.0(5)$ & $-4.6(2)$ & $-165.4(2)$ \\
$\mathrm{C}(6)-\mathrm{C}(5)-\mathrm{C}(8)-\mathrm{C}(9)$ & $179.5(3)$ & $175.87(15)$ & $15.8(3)$ \\
$\mathrm{C}(5)-\mathrm{C}(8)-\mathrm{C}(9)-\mathrm{C}(10)$ & $178.9(3)$ & $178.74(15)$ & $-179.94(17)$ \\
$\mathrm{C}(8)-\mathrm{C}(9)-\mathrm{C}(10)-\mathrm{C}(11)$ & $-178.5(3)$ & $-178.21(15)$ & $19.0(3)$ \\
$\mathrm{C}(8)-\mathrm{C}(9)-\mathrm{C}(10)-\mathrm{N}(1)$ & $0.4(5)$ & & $-161.1(2)$ \\
$\mathrm{N}(1)-\mathrm{C}(10)-\mathrm{C}(11)-\mathrm{C}(12)$ & $-0.8(5)$ & $0.0(3)$ & $1.9(3)$ \\
$\mathrm{C}(9)-\mathrm{C}(10)-\mathrm{C}(11)-\mathrm{C}(12)$ & $178.1(3)$ & $178.96(14)$ & $-178.31(19)$ \\
$\mathrm{C}(9)-\mathrm{C}(10)-\mathrm{N}(1)-\mathrm{C}(14)$ & $-178.8(3)$ & & $178.04(16)$ \\
$\mathrm{C}(10)-\mathrm{C}(11)-\mathrm{C}(12)-\mathrm{C}(13)$ & $0.7(5)$ & & $0.0(3)$ \\
$\mathrm{C}(11)-\mathrm{C}(12)-\mathrm{C}(13)-\mathrm{C}(14)$ & $-0.1(5)$ & & $-1.6(3)$ \\
$\mathrm{C}(12)-\mathrm{C}(13)-\mathrm{C}(14)-\mathrm{N}(1)$ & $-0.6(5)$ & & $1.4(3)$ \\
$\mathrm{C}(13)-\mathrm{C}(14)-\mathrm{N}(1)-\mathrm{C}(10)$ & $0.6(5)$ & $0.1(2)$ & $0.5(3)$ \\
$\mathrm{C}(11)-\mathrm{C}(10)-\mathrm{N}(1)-\mathrm{C}(14)$ & $0.1(4)$ & & $-2.1(3)$ \\
$\mathrm{C}(8)-\mathrm{C}(9)-\mathrm{C}(10)-\mathrm{C}(14)$ & & $1.2(3)$ & \\
$\mathrm{C}(14)-\mathrm{C}(10)-\mathrm{C}(11)-\mathrm{C}(12)$ & & $-0.5(2)$ & \\
$\mathrm{C}(11)-\mathrm{C}(10)-\mathrm{C}(14)-\mathrm{C}(13)$ & & $0.4(2)$ & \\
$\mathrm{C}(9)-\mathrm{C}(10)-\mathrm{C}(14)-\mathrm{C}(13)$ & & $-178.99(15)$ & \\
$\mathrm{C}(11)-\mathrm{C}(12)-\mathrm{N}(1)-\mathrm{C}(13)$ & & $0.5(2)$ & \\
$\mathrm{C}(14)-\mathrm{C}(13)-\mathrm{N}(1)-\mathrm{C}(12)$ & & $-0.6(2)$ & \\
$\mathrm{O}(2)-\mathrm{C}(1)-\mathrm{C}(2)-\mathrm{C}(3)$ & & & $-9.3(3)$ \\
$\mathrm{O}(2)-\mathrm{C}(1)-\mathrm{C}(2)-\mathrm{C}(7)$ & & & $171.38(17)$ \\
\hline
\end{tabular}

In contrast, for III, the structure was comprised of three groups, phenyl, pyridyl and a double bond; the $-\mathrm{COOH}$ group was not completely coplanar due most likely to the intermolecular H-bonding between $\mathrm{OH}$ group of one molecule $\mathrm{N}$ and nitrogen atoms of a symmetry-related pyridine ring $\left[\mathrm{O}(2)-\mathrm{H}(2) \cdots \mathrm{N}(1), 1.669 \AA, \mathrm{O}(2)-\mathrm{H}(2), 0.97(3) \AA, \mathrm{O}(1)^{\cdots} \mathrm{N}(1) 2.642 \AA, \mathrm{O}(2)-\mathrm{H}(2)^{\cdots} \mathrm{N}(1) 1^{178.29^{\circ}}\right]$, symmetry code: $2-x,-1 / 2+y, 1-z$. Figure 2 illustrates that in the molecular structure, the styryl-moiety is moved out the plane that contains the pyridine ring. The torsion angle (Table 4), between $\mathrm{C}(6)-\mathrm{C}(5)-$ $\mathrm{C}(8)-\mathrm{C}(9)$ is $15.8(3)^{\circ}$ and between $\mathrm{C}(4)-\mathrm{C}(5)-\mathrm{C}(8)-\mathrm{C}(9)$ is $-165.4(2)^{\circ}$. With respect to the pyridine ring, the plane was moved out with torsion angles between $\mathrm{C}(8)-\mathrm{C}(9)-\mathrm{C}(10)-\mathrm{N}(1)$ of $-161.1(2)^{\circ}$, between $\mathrm{C}(11)-\mathrm{C}(10)-\mathrm{C}(9)-\mathrm{C}(8)$ of $19.0(3)^{\circ}$, and between $\mathrm{C}(15)-\mathrm{C}(16)-\mathrm{C}(18)-\mathrm{C}(19)$ of $-15.7(2)^{\circ}$.

Figures 1 and 2 show that compound III displayed a rotation in the opposite direction to that of compounds I and II. This was an interesting outcome because even though the double bond exhibited a trans configuration, its position showed a different arrangement compared to several previously reported styrylpyridines [43-51]. According to a recently calculated report [52] of the energy for the conformation of 2-styrylpyridine, the nitrogen atom of the pyridine could rotate around the bond between the double bond and the pyridine ring to diminish the steric effects of the proton of the ring with the protons of double bond $\mathrm{H}(1)$ or $\mathrm{H}(2)$ (Scheme 1). In the calculated results, the energy corresponding to the syn form (a) is $5.561 \mathrm{KJ} \mathrm{mol}^{-1}$ and for trans form (b) is $4.536 \mathrm{KJ} \mathrm{mol}^{-1}$, indicating that rotamer (b) should be more stable than (a), by almost 3 orders of magnitude order at the theory level. In contrast to 
the X-ray crystallography of III, in its molecular structure, the proton $\mathrm{H}(1)$ is located syn to the nitrogen atom even in the presence of a free pair of electrons that should contribute to destabilization of the molecule, according to different reports. This configuration is an indication of the possible presence of different rotamers. However, the molecular structure of III was obtained with proton H(1) located in a syn configuration. The molecular packing also showed weaker intermolecular interactions in form of face to face and side by side $(\pi-\pi)$ molecular stacking.
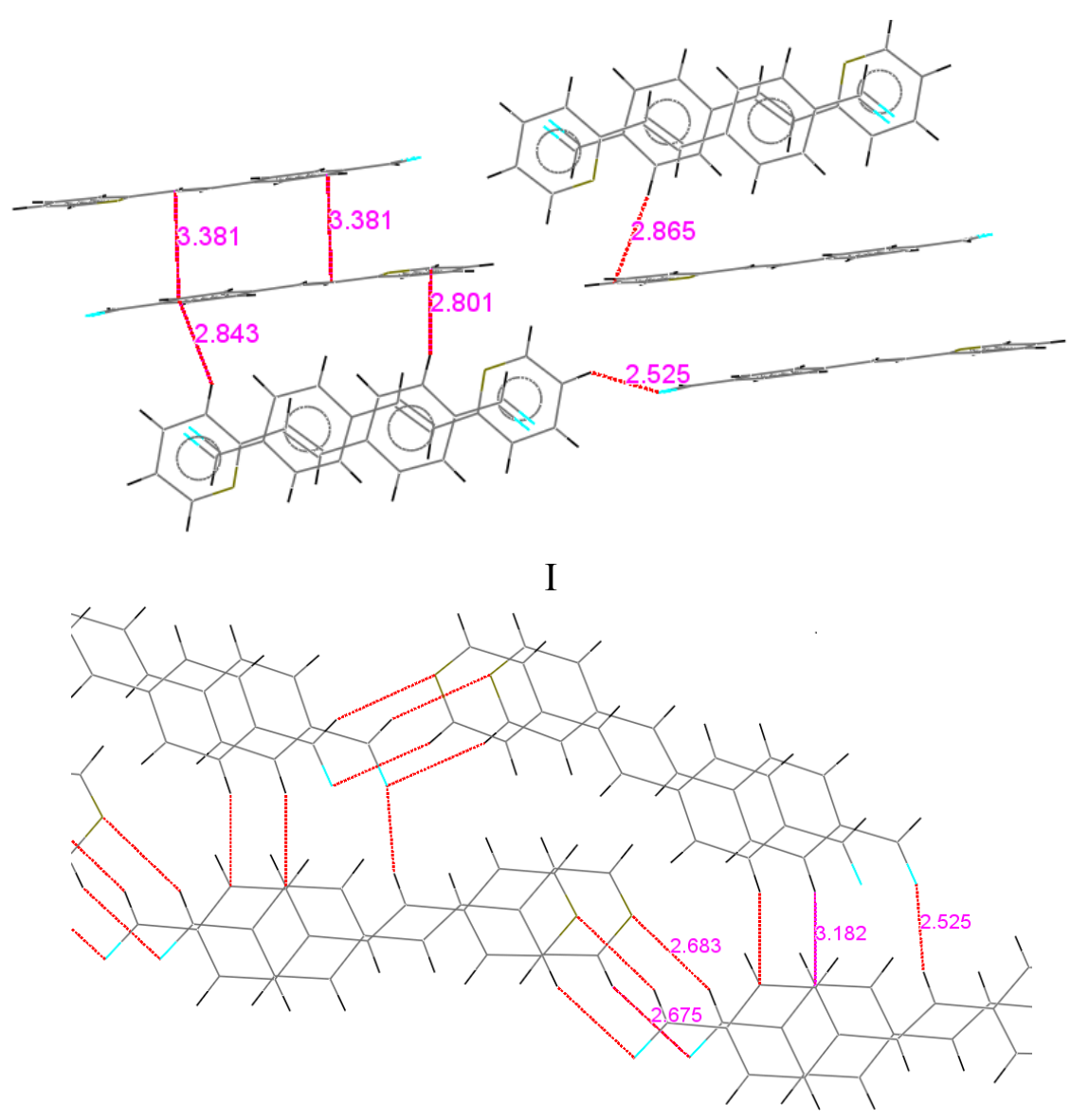

II

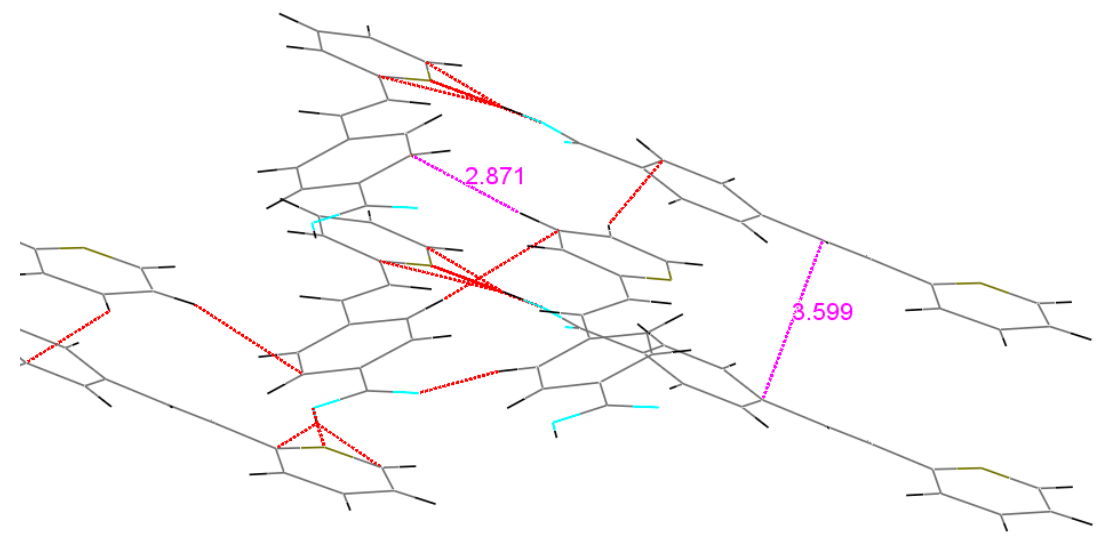

III

Figure 2. Molecular crystal packing of I, II and III short contacts (dashed red lines). 


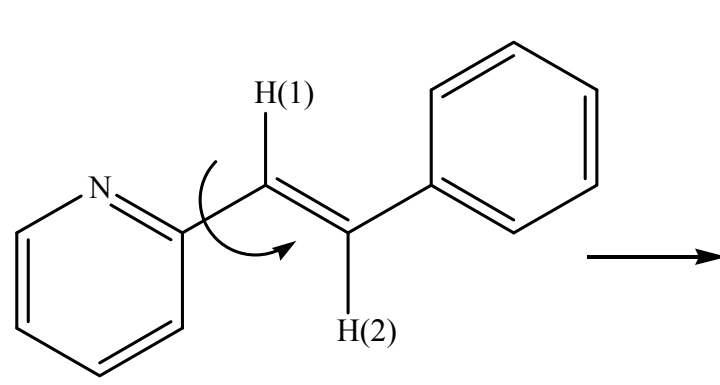

$\mathbf{a}$

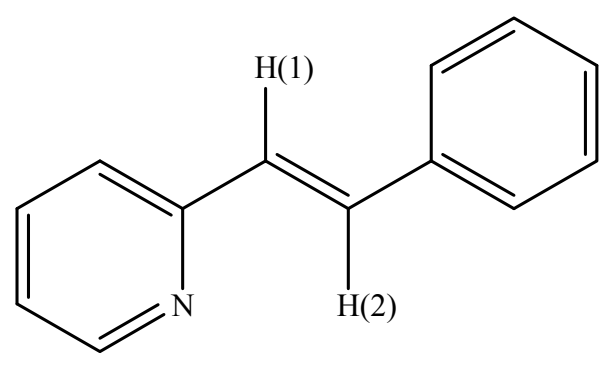

b

Scheme 1. Rotamers where the pyridine group could be in syn (a) or anti (b) configuration for 2-styrylpyridine.

\subsection{Characterization of trans-4-((E)-2-(Pyridin-2-yl)vinyl)benzamido-TEMPO (V)}

Characterization by IR of trans-4-((E)-2-(pyridin-2-yl)vinyl)benzamido-TEMPO (V) (Figure 3) showed characteristic bands at $1661 \mathrm{~cm}^{-1}$ and $1587 \mathrm{~cm}^{-1}$ which were assigned to the $v(\mathrm{C}=\mathrm{O})$ and $v(\mathrm{C}-\mathrm{N})$ corresponding to the amide group $(-\mathrm{C}(\mathrm{O}) \mathrm{NH})$ present in the compound. Also, the vibration corresponding to $v\left(\mathrm{~N}-\mathrm{O}^{\bullet}\right)$ from nitroxyl group is observed at $1360 \mathrm{~cm}^{-1}$, which is in agreement with the experimental and calculations reports [56-58]. In addition, bands at $3545 \mathrm{~cm}^{-1}, 3008 \mathrm{~cm}^{-1}, 2925 \mathrm{~cm}^{-1}$ and $977 \mathrm{~cm}^{-1}$ which correspond to $v(\mathrm{~N}-\mathrm{H}), v(\mathrm{C}-\mathrm{H}$, aromatic $), v\left(\mathrm{CH}_{2}\right)$ and $\delta(=\mathrm{C}-\mathrm{H}$, trans $)$ vibration are observed. Also, at $1259 \mathrm{~cm}^{-1}$ there is a weak band corresponding to the interaction between $\mathrm{N}-\mathrm{H}$ bending and C-N stretching of the amide group. This spectral evidence gave information about the formation of V. Currently, investigations to acquire the ${ }^{1} \mathrm{H}-\mathrm{NMR}$ spectrum of the corresponding hydroxylamine analogue are underway. The outcome of these studies should give more evidence regarding the conformation of $\mathbf{V}$.

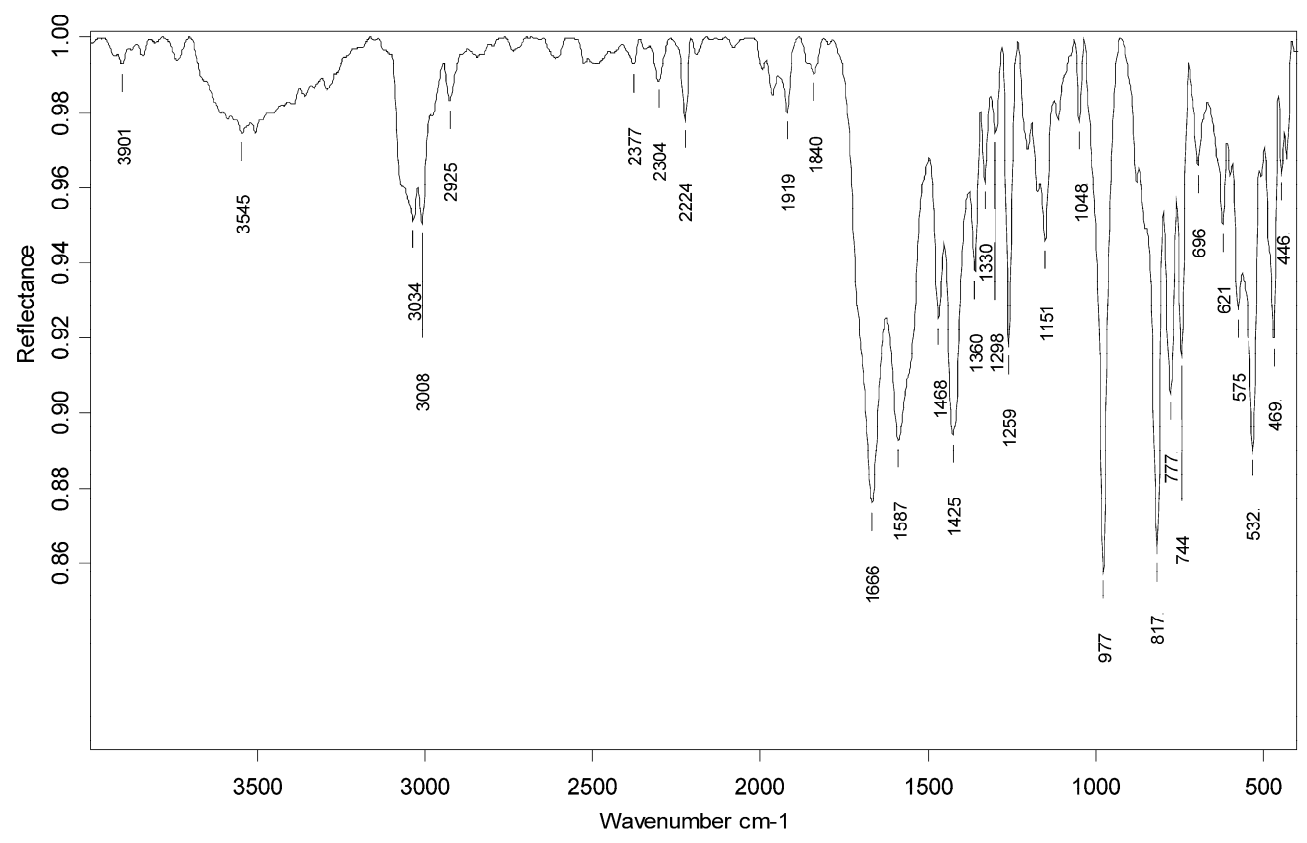

Figure 3. IR spectrum corresponding to trans-4-((E)-2-(pyridin-2-yl)vinyl)benzamido-TEMPO (V). 


\subsection{One Photon Absorption Characterization}

Absorption spectra of the 2-styrylpyridine and 4-styrylpyridine (Figure 4) were recorded in methanol in allow comparison with the compounds I, II, III and IV and to evaluate the effect of the -CHO and $-\mathrm{COOH}$ substituents (Figures 5 and 6). An insignificant red shift in the absorption wavelength occurred due to presence of $-\mathrm{COH}$ for both isomers. The 2-styrylpyridine compound exhibited one band at 309 $\mathrm{nm}$ corresponding to the $\pi \rightarrow \pi^{*}$ transition characteristic for a double bond in the trans position; this result agreed well with previous reports $[45,50,52]$. 4-Styrylpyridine exhibited an absorption band at 303 $\mathrm{nm}$ corresponding to the $\pi \rightarrow \pi *$ transition due to the double bond, which is in agreement with theoretical reports [59,60]. The spectra for both isomers I and II displayed a significant red shift as compared with the corresponding 2- and 4-styrylpyridine compounds (Figure 5) due to the presence of the $-\mathrm{COH}$ in both isomers. Compound I exhibited a stronger red shift than did II. However, for compounds III and IV in the acid form, the $-\mathrm{COOH}$ group had little effect on the absorption wavelength position (Figure 6). Compounds III-IV showed an absorption at $232 \mathrm{~nm}$, which could be assigned to the transition of the $\mathrm{n} \rightarrow \pi^{*}$ of the electron-withdrawing $-\mathrm{COOH}$. This red shift was related to intermolecular hydrogen bonding interactions between two adjacent groups. The spectrum of compound $\mathbf{V}$ (Figure 7) was completely different, but the band at $\lambda_{\max } 289 \mathrm{~nm}$ could attribute to the chromophore N-O present in the structure [61].


Figure 4. Absorption spectra of 2-styrylpyridine and 4-styrylpyridine in methanol.
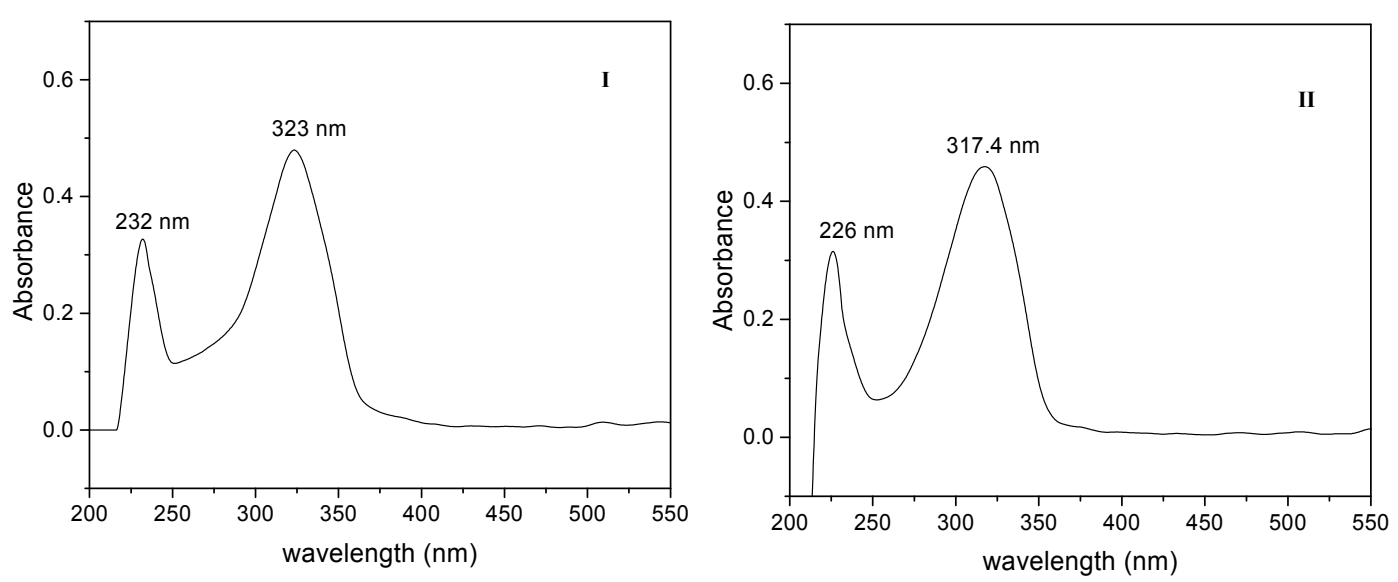

Figure 5. Absorption spectra of (I) and (II). 



Figure 6. Absorption spectra of the (III) and (IV) respectively.

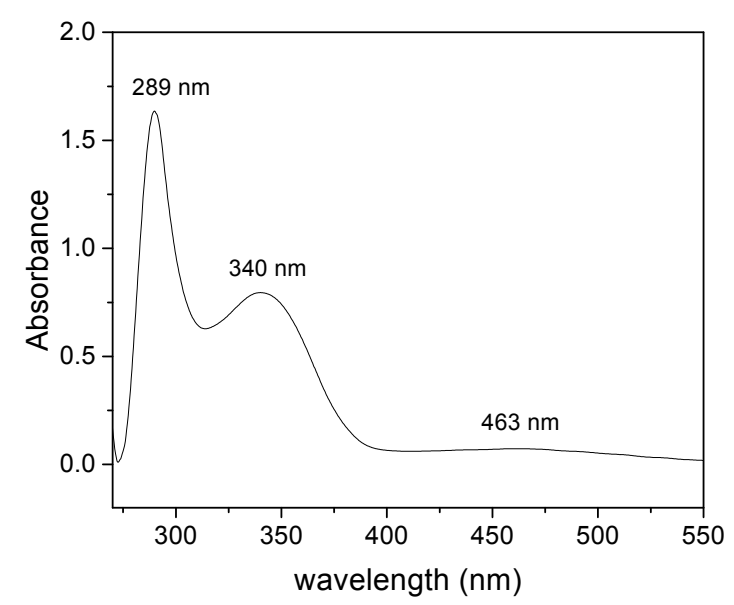

Figure 7. Absorption spectrum of (V).

\section{Experimental Section}

\subsection{Materials and Instrumentation}

Methylpyridines, $p$-terephthalaldehyde, $\mathrm{NH}_{2}$-TEMPO, oxalyl chloride, $\mathrm{DMF}$, and $\mathrm{CH}_{2} \mathrm{Cl}_{2}$, were acquired from Aldrich Chemical Co. (Toluca, México) and were purified before use. The Jones reagent was prepared during the oxidation reaction. Melting points were measured with an SEV $\left(0-300{ }^{\circ} \mathrm{C}\right)$ apparatus and were reported as uncorrected values. IR spectra of the products were recorded on a Vertex (model 70, Bruker Optics, Ettlingen, Germany) 750 FT-IR spectrophotometer by attenuated total reflectance (ATR). ${ }^{1} \mathrm{H}-\mathrm{NMR}$ and ${ }^{13} \mathrm{C}$-NMR spectra were obtained in $\mathrm{CDCl}_{3}$ and DMSO- $d_{6}$, on a Varian $400 \mathrm{MHz}$ NMR spectrometer (Varian NMR, Walnut Creek, CA, USA). The electron ionization (EI) spectra were acquired on a JeolMStation 700-D mass spectrometer (Jeol USA, Peabody, MA, USA). UV-Vis spectra were acquired with a Spectrometer SD2000 (Ocean Optics, Dunedin, FL, USA) equipped with a pulse Xenon light source PX-2 (Ocean Optics). The solvent used for measurements in solution was methanol of spectroscopic grade and was preliminarily checked for the absence of absorbing impurities within the scanned spectral ranges. 


\subsection{Synthesis and Characterization of Precursors $\mathbf{I}-\mathbf{I V}$}

The precursors trans-4[-(2-(pydridin-2-yl)vinyl)]benzaldehyde (I) and trans-4[-(2-(pyridin-4yl)vinyl]-benzaldehyde (II) were prepared as follows. The basic structures of (I) and (II) were modified by oxidation of the - $\mathrm{COH}$ group to a carboxylic acid (III and IV) (Scheme 2). Then, trans-(E)-4-(2(pydridin-2-yl)vinylbenzoic acid (III) was condensed with amino-TEMPO to obtain the trans-4-((E)-2(pyridin-2-yl)vinyl)benzamido-TEMPO (V) (Scheme 3).<smiles>Cc1ccncn1</smiles>

Scheme 2. Syntheses of trans-4-(2-(pyridin-2-yl)vinylbenzaldehyde (I), trans-4-(2(pyridin-4-yl)vinylbenzaldehyde (II), trans-4-(2-(pydridin-2-yl)vinylbenzoic acid (III), (E)4-(2-(pydridin-4-yl)vinylbenzoic acid (IV).<smiles>CC(=O)C1(C)CC(N)CC(C)(C)N1O</smiles>

Scheme 3. Synthesis of trans-4-((E)-2-(pyridin-2-yl)vinyl)benzamido-TEMPO (V).

Compounds I and II were obtained by slight modifications of the reported methodology [43]. Terephthaldehyde (2.35 g; $25.3 \mathrm{mmol})$ with 2-methylpyridine for I and 4-methylpyridine for II ( $2.5 \mathrm{~mL}$; $25.3 \mathrm{mmol}$ ) were refluxed in the absence of a condensing agent at $120^{\circ} \mathrm{C}$ for $50-60 \mathrm{~h}$. In both cases the reaction mixtures were oily and had brown or red-brown color. The mixture was treated with a solution of $2 \mathrm{~N} \mathrm{NaOH}(643 \mathrm{~mL})$ to precipitate a solid. The products were purified by recrystallization with cyclohexane and characterized by IR, ${ }^{1} \mathrm{H}-\mathrm{NMR}$, EI and single crystal X-ray crystallography. The yields 
were $18.81 \%$ (I) and $20.12 \%$ (II). The melting point was $80-81{ }^{\circ} \mathrm{C}$ and $109-111^{\circ} \mathrm{C}$ for (I) and (II), respectively.

(I) $\mathrm{IR}(\mathrm{KBr}), \widetilde{v} / \mathrm{cm}^{-1}$ : 1695 (sharp, $\left.v \mathrm{C}=\mathrm{O}\right), 1599$ (w, vC=N Py), 1600 (broad, $v \mathrm{C}=\mathrm{C}$ Ar), 974 (s, $\delta \mathrm{C}-\mathrm{H} \mathrm{CHR}_{1}=\mathrm{CHR}_{2}$ in trans $) .{ }^{1} \mathrm{H}-\mathrm{NMR}\left(500 \mathrm{MHz}, \mathrm{CD}_{3} \mathrm{Cl}\right) \delta(\mathrm{ppm}): 10.03(\mathrm{~s}, 1 \mathrm{H}), 8.67-8.66(\mathrm{dd}, 1 \mathrm{H}$, $\left.J_{\mathrm{H}-\mathrm{H}}=5.5 ; 4.5 ; 0.5\right), 7.93-7.91\left(\mathrm{dd}, 2 \mathrm{H}, J_{\mathrm{H}-\mathrm{H}}=8 ; 6.5 ; 1.5\right), 7.76-7.72\left(\mathrm{~m}, 4 \mathrm{H}, J_{\mathrm{H}-\mathrm{H}}=8.5 ; 6 ; 5.5 ; 5.0\right)$, 7.46-7.44 (d, 1H, $\left.J_{\mathrm{H}-\mathrm{H}}=8\right), 7.35-7.32\left(\mathrm{~d}, 1 \mathrm{H}, J_{\mathrm{H}-\mathrm{H}}=16\right), 7.25-7.21\left(\mathrm{dd}, 1 \mathrm{H}, J_{\mathrm{H}-\mathrm{H}}=16\right)$. EI $(\mathrm{m} / z, \%)$ : molecular ion 209 [M+, 25], 208 (92), 180 (15), 178 (6), 133 (100), 105 (52), 77 (50).

(II) IR (KBr): $\widetilde{v} / \mathrm{cm}^{-1}: 1688$ (sharp, $\left.v \mathrm{C}=\mathrm{O}\right), 1567(\mathrm{w}, \mathrm{vC}=\mathrm{N}, \mathrm{Py}), 1598$ (broad, $\left.v \mathrm{C}=\mathrm{C}, \mathrm{Ar}\right), 979$ (s, $\delta \mathrm{C}-\mathrm{H} \mathrm{CHR}{ }_{1}=\mathrm{CHR}_{2}$ in trans $) .{ }^{1} \mathrm{H}-\mathrm{NMR}(500 \mathrm{MHz}),\left(\mathrm{CD}_{3} \mathrm{Cl}\right): \delta(\mathrm{ppm}): 10.03(\mathrm{~s}, 1 \mathrm{H}), 8.64-8.63(\mathrm{~d}, 2 \mathrm{H}$, $\left.J_{\mathrm{H}-\mathrm{H}}=6\right), 7.93-7.91\left(\mathrm{dd}, 2 \mathrm{H}, J_{\mathrm{H}-\mathrm{H}}=8.5\right), 7.37-7.34\left(\mathrm{~d}, 1 \mathrm{H}, J_{\mathrm{H}-\mathrm{H}}=16\right), 7.19-7.16\left(\mathrm{~d}, 1 \mathrm{H}, J_{\mathrm{H}-\mathrm{H}}=16\right)$, $7.71-7.7\left(\mathrm{~d}, 2 \mathrm{H}, J_{\mathrm{H}-\mathrm{H}}=8.5\right), 7.42-7.40\left(\mathrm{dd}, 2 \mathrm{H}, J_{\mathrm{H}-\mathrm{H}}=8 ; 5\right) . \mathrm{EI}(\mathrm{m} / \mathrm{z}, \%): 209\left[\mathrm{M}^{+}, 100\right], 208(77), 180$ (96), 178 (10), 104 (7), 76 (15).

3.2.1. Synthesis and Characterization of trans-(E)-4-(2-(Pydridin-2-yl)vinylbenzoic acid and trans- $(E)$ 4-(4-(pydridin-4-yl)vinylbenzoic acid (III and IV)

For both compounds, the oxidation reaction used the Jones reagent, which was prepared with $0.66 \mathrm{~g}$ of $\mathrm{CrO}_{3}(6.6 \mathrm{mmol})$ dissolved in $\mathrm{H}_{2} \mathrm{O}$. To the solution, an adequate quantity of $\mathrm{H}_{2} \mathrm{SO}_{4}$ was added until a red precipitate formed. An acetone solution with $1.38 \mathrm{~g}(6.6 \mathrm{mmol})$ I or II was prepared at room temperature and it was added to the solution of Jones reagent dissolved in small quantity of water. The reaction mixture was refluxed for about $24 \mathrm{~h}$. After the mixture was treated with $\mathrm{NaHCO} / \mathrm{H}_{2} \mathrm{O}$ to reach $\mathrm{pH}=7$, a yellow precipitate (III or IV) formed. The solid III was purified by recrystallization with a solvents mixture of $\mathrm{H}_{2} \mathrm{O}$ /acetone (80:20), whereas IV was recrystallized with DMF: $\mathrm{CH}_{3} \mathrm{OH}(20: 80)$. Finally, the compounds were treated with heated hexane to eliminate any remains of I and II. The products III and IV were characterized by IR, ${ }^{1} \mathrm{H}-,{ }^{13} \mathrm{C}-\mathrm{NMR}$ and EI. Compound III was further characterized by single crystal X-ray crystallography. The yields were $39.40 \%$ for III and $11.27 \%$ for IV; the melting point of III was of $217-220^{\circ} \mathrm{C}$ while IV did not present a melting point $>300{ }^{\circ} \mathrm{C}$.

(III) IR (KBr): $\widetilde{v}_{/ \mathrm{cm}^{-1}}: 1692$ ( $\mathrm{s}$ and broad, $v \mathrm{C}=\mathrm{O}$ ), 1601 (w, $\left.\mathrm{vC}=\mathrm{C}, \mathrm{Ar}\right), 1569(\mathrm{vC}=\mathrm{N}, \mathrm{Py}), 1281$ (s, wide, $v \mathrm{C}-\mathrm{O}), 964\left(\mathrm{~s}, \delta \mathrm{C}-\mathrm{H} \mathrm{CHR}_{1}=\mathrm{CHR}_{2}\right.$ in trans). ${ }^{1} \mathrm{H}-\mathrm{NMR}(500 \mathrm{MHz}),\left(\mathrm{DMSO}-d_{6}\right): \delta(\mathrm{ppm}): 12.97$ (wide signal, $1 \mathrm{H}) 8.61-8.60\left(\mathrm{dd}, 1 \mathrm{H}, J_{\mathrm{H}-\mathrm{H}}=5.5,4.5,3.5\right), 7.97-7.95\left(\mathrm{dd}, 2 \mathrm{H}, J_{\mathrm{H}-\mathrm{H}}=8\right), 7.84-7.58(\mathrm{~m}$, $\left.4 \mathrm{H}, J_{\mathrm{H}-\mathrm{H}}=16,8,6,5.5\right), 7.60-7.58\left(\mathrm{dd}, 1 \mathrm{H}, J_{\mathrm{H}-\mathrm{H}}=8\right), 7.48-7.45\left(\mathrm{dd}, 1 \mathrm{H}, J_{\mathrm{H}-\mathrm{H}}=16\right), 7.31-7.28(\mathrm{~m}, 1 \mathrm{H}$, $\left.J_{\mathrm{H}-\mathrm{H}}=5.5\right) .{ }^{13} \mathrm{C}(500 \mathrm{MHz}),\left(\mathrm{DMSO}-d_{6}\right) \delta(\mathrm{ppm}): 167.73(\boldsymbol{C O O H}), 155.16(\mathrm{Ar}), 150.29(\mathrm{py}), 141.35$ (py), 137.61 (Ar), 131.55 (Ar), $131.15(\boldsymbol{C H}=\mathrm{CH}), 130.8$ (Ar), $130.49(\mathrm{Ar}), 127.76(\mathrm{CH}=\boldsymbol{C H}), 123.62$ (py), 123.52 (ру). EI (m/z, \%): $225\left[\mathrm{M}^{+}, 22\right], 224$ (100), 178 (7), 87 (15).

(IV) IR (KBr): $\widetilde{v} / \mathrm{cm}^{-1}: 2435$ (s, wide, $\mathrm{COH}^{\cdots} \mathrm{OC}$ ), 1699 (s and broad, $\left.v \mathrm{C}=\mathrm{O}\right), 1604(\mathrm{w}, v \mathrm{C}=\mathrm{C}, \mathrm{Ar}$ ), $1567(\mathrm{w}, v \mathrm{C}=\mathrm{N}, \mathrm{Py}), 1286(\mathrm{~s}$, wide, $v \mathrm{C}-\mathrm{O}), 959$ (s, $\delta \mathrm{C}-\mathrm{H} \mathrm{CHR}_{1}=\mathrm{CHR}_{2}$ in trans). ${ }^{1} \mathrm{H}-\mathrm{NMR}(500 \mathrm{MHz})$, $\left.\left(\mathrm{CD}_{3}\right)_{2} \mathrm{SO}\right), \delta(\mathrm{ppm}): 8.59-8.58\left(\mathrm{dd}, 2 \mathrm{H}, J_{\mathrm{H}-\mathrm{H}}=5.5\right), 7.98-7.96\left(\mathrm{~d}, 2 \mathrm{H}, J_{\mathrm{H}-\mathrm{H}}=8.5\right), 7.79-7.77(\mathrm{dd}, 2 \mathrm{H}$, $\left.J_{\mathrm{H}-\mathrm{H}}=8\right), 7.65-7.60\left(\mathrm{~m}, 3 \mathrm{H}, J_{\mathrm{H}-\mathrm{H}}=17.5,6\right), 7.43-7.39\left(\mathrm{dd}, 1 \mathrm{H}, J_{\mathrm{H}-\mathrm{H}}=16.5\right) .{ }^{13} \mathrm{C}\left(\mathrm{DMSO}-d_{6}\right), \delta(\mathrm{ppm})$ : $167.49(\boldsymbol{C O O H}), 150.6$ (ру), 144.31 (рy), 140.85 (Ar), 132.42 (Ar), $131.0(\boldsymbol{C H}=\mathrm{CH}), 130.29$ (Ar), 
128.90 (Ar), 127.57 (CH=CH), 121.57 (py). EI (m/z, (\%): 225 [M+, 18], 206 (90), 180 (60), 178 (20), $152(41), 102(7), 76(10)$.

3.2.2. Condensation Reaction to Obtain the trans-4-((E)-2-(Pyridin-2-yl)vinyl)benzamido-TEMPO (V)

To synthesize $\mathbf{V}$, carboxylic acid III was reacted with 4-NH2-TEMPO using oxalyl chloride, DMF and $\mathrm{CH}_{2} \mathrm{Cl}_{2}$ [62] (Scheme 3). To a three-necked flask was added $0.22 \mathrm{~g}$ (1 mmol) of III dissolved in $5 \mathrm{~mL}$ of DMF at $4{ }^{\circ} \mathrm{C}$. The mixture was reacted for $30 \mathrm{~min}$ with stirring and then oxalyl chloride $(0.22 \mathrm{~mL}, 2 \mathrm{mmol})$ was added, and the temperature was increased to room temperature. 4-Amino TEMPO ( $\mathrm{NH}_{2}$-TEMPO) (0.170 $\left.\mathrm{g}, 1 \mathrm{mmol}\right)$ dissolved in DMF was then added. The mixture was stirred for $48 \mathrm{~h}$ at $90^{\circ} \mathrm{C}$. During this time the mixture changed from light yellow to orange and finally to orangepink. After the reaction time, the mixture was treated with acetone $/ \mathrm{H}_{2} \mathrm{O}(2: 1)$ to precipitate an orange solid, which was isolated by vacuum-filtration. The solid was purified by recrystallization with a mixture of EtOH/ethyl acetate (1:1); yield was 35\% with m.p. of $140-142{ }^{\circ} \mathrm{C}$.

\subsection{Crystallization of Compounds I, II and III}

Crystals of I were obtained with $55 \mathrm{mg}$ of I dissolved in $3 \mathrm{~mL}$ of a mixture of solvents THF/hexane (80:20) and kept at room temperature. After $24 \mathrm{~h}$, colorless crystals were formed.

Crystals of II were obtained with $55 \mathrm{mg}$ of compound II dissolved in $5 \mathrm{~mL}$ of EtOH/cyclohexane (80:20). The solution was kept at room temperature and allowed to slowly evaporate and after 2 days, crystals were formed.

Crystals of III were obtained with $4 \mathrm{mg}$ of compound III dissolved in $5 \mathrm{~mL}$ of MeOH/DMF (80:20) at high temperature. The solution was kept at $4{ }^{\circ} \mathrm{C}$ and allowed to slowly evaporate. After 8 days, crystals were obtained.

\subsection{X-ray Crystallography}

All reflection intensities of I and III were measured at 110(2) K and for II at 100(2) K using a SuperNova diffractometer (equipped with Atlas detector) with $\mathrm{Cu} K \alpha$ radiation $(\lambda=1.54178 \AA$ ). The program CrysAlisPro (Version 1.171.36.32 2013, Agilent Technologies, Santa Clara, CA, USA) was used to refine the cell dimensions and for data reduction. The structures were solved with the program SHELXS-2013 and were refined on $F^{2}$ with SHELXL-2013 [63]. Empirical absorption correction using spherical harmonics implemented in the SCALE3 ABSPACK scaling algorithm was applied using CrysAlisPro (Version 1.171.36.32). The temperature of the data collection was controlled using the system Cryojet (manufactured by Oxford Instruments, Abingdon, Oxford, UK). The H atoms were placed at calculated positions using the instructions AFIX 43 with isotropic displacement parameters having values 1.2 times $U$ eq of the attached $\mathrm{C}$ atoms. The $\mathrm{H}$ atom attached to $\mathrm{O}_{2}$ was found from the difference Fourier map, and its coordinates were refined freely.

\section{Conclusions}

We have synthesized precursors of styrylpyridine in good yield and they were well characterized. The crystallography data gave evidence that the molecular structure of the double bond was in the trans 
conformation, as well as that one of the phenyl rings in III was twisted appreciably and featured an intermolecular hydrogen bond with one of the neighboring complexes to form a one-dimensional or two-dimensional network. These intermolecular interactions would induce cooperative effects, leading to good conjugation properties. Finally, this methodology has developed a general method to functionalize the synthesized precursors III-VI with $\mathrm{NH}_{2}$-TEMPO.

\section{Supplementary Materials}

Crystallographic data (excluding structure factors) reported in this paper have been deposited with the Cambridge Crystallographic Data Centre as supplementary publication no. CCDC 1054889, 1054890, 1054891. Copies of available material can be obtained, free of charge, on application to the CCDC, 12 Union Road. Cambridge CB2 IEZ, UK, fax: +44-(0)1223-336033 or e-mail: deposit@ccdc.cam.ac.uk.

\section{Acknowledgments}

The authors wish to express their gratitude to VIEP-BUAP (projects PEZM-NAT15-G, CHCV-NAT15-G and SOMJ-NAT15-I), PROMEP-SEP (Thematic network of collaboration and CONACyT (projects 157552 and 183833), as well as to Maxime A. Siegler (Johns Hopkins University) for his valuable help with the X-ray crystallography and Vladimir Carranza for assistance with EI mass spectrometry.

\section{Author Contributions}

Conceived and designed the experiments: M.C., G.S-M. and M.J.P.; Performed the experiments: M.C. and A.L.S.; Analyzed the data: M.J.P., G.S-M.; Contributed reagents/materials/analysis tools: M.J.P., G.S-M., V.M.CH. and M.E.C.; Wrote the paper G.S-M. and M.J.P. All authors read and approved the final manuscript.

\section{Conflicts of Interest}

The authors declare no conflict of interest.

\section{References}

1. Hoffman, A.K.; Henderson, A.T. A new stable free radical: Di-t-butylnitroxide. J. Am. Chem. Soc. 1961, 83, 4671-4672.

2. Korshak, Y.V.; Medvedeva, T.V.; Ovchinnikov, A.A.; Spector, V.N. Organic polymer ferromagnet. Nature 1987, 326, 370-372.

3. Mitchell, J.B.; Samuni, A.; Krishna, M.C.; DeGraff, W.G.; Ahn, M.S.; Samuni, U.; Russo, A. Biologically active metal-independent superoxide dismutase mimics. Biochemistry 1990, 29, 2802-2807.

4. Cuzzocrea, S.; McDonald, M.C.; Mazzon, E.; Siriwardena, D.; Costantino, G.; Fulia, F.; Cucinotta, G.; Gitto, E.; Cordaro, S.; Barberi, I.; et al. Effects of tempol, a membrane-permeable radical scavenger, in a gerbil model of brain injury. Brain Res. 2000, 875, 96-106. 
5. Miura, Y.; Utsumi, H.; Hamada, A. Antioxidant activity of nitroxide radicals in lipid peroxidation of rat liver microsomes. Arch. Biochem. Biophys. 1993, 300, 148-156.

6. Li, H.; Xu, K.Y.; Zhou, L.; Kálai, T.; Zweier, J.L.; Hideg, K.; Kuppusamy, P. A pyrroline derivative of mexiletine offers marked protection against ischemia/reperfusion-induced myocardial contractile dysfunction. J. Pharmacol. Exp. Ther. 2000, 295, 563-571.

7. Mitchell, J.B.; DeGraff, W.; Kaufman, D.; Krishna, M.C.; Samuni, A.; Finkelstein, E.; Ahn, M.S.; Hahn, S.M.; Gamson, J.; Russo, A. Inhibition of oxygen-dependent radiation-induced damage by the nitroxide superoxide dismutase mimic, Tempol. Arch. Biochem. Biophys. 1991, 289, 62-70.

8. Fritscher, J.; Beyer, M.; Schiemann, O. Synthesis, crystal structure and magnetic properties of a novel nitroxide biradical. Theoretical investigation of the exchange mechanism. Chem. Phys. Lett. 2002, 364, 393-401.

9. Fujiwara, H.; Fujiwara, E.; Kobayashi, H. Synthesis, structures and properties of new organic donors connecting to a TEMPO radical through a pyrrolidine ring. Synth. Met. 2003, 133-134, 359-360.

10. Tudose, M.; Ionita, P.; Dunitrascu, F.; Draghici, C.; Caproiu, M.T.; Covaci, I.C.; Constantinescu, T.; Banciu, M.; Balaban, A.T. Synthesis and properties of dinitrobenzamido-TEMPO derivatives. ARKIVOC 2005, 225-237.

11. Kasumov, V.T.; Ucar, I.; Bulut, A.; Yerli, Y. Synthesis, crystal structure and intermolecular magnetic interactions of a new $N$-TEMPO-3,5-di-tert-butylsalicylaldimine radical. Solid State Sci. 2011, 13, 1852-1857.

12. Cicogna, F.; Coiai, S.; Pinzino, C.; Ciardelli, F.; Passaglia, E. Fluorescence polyolefins by free radical post-reactor modification with functional nitroxides. React. Funct. Polym. 2012, 72, 695-702.

13. Lozinsky, E.; Martin, V.V.; Berezina, T.A.; Shames, A.I.; Weis, A.L.; Likhtenshtein, G.I. Dual fluorophore-nitroxide probes for analysis of vitamin $\mathrm{C}$ in biological liquids. J. Biochem. Biophys. Methods 1999, 38, 29-42.

14. Chen, J.-L.; Zhuo S.-J.; Wu, Y.-Q.; Fang, F.; Li, L.; Zhu, C.-Q. High selective determination iron(II) by its enhancement effect on the fluorescence of pyrene-tetramethylpiperidinyl (TEMPO) as a spin fluorescence probe. Spectrochim. Acta Part A 2006, 63, 438-443.

15. Sato, S.; Suzuki, M.; Soma, T.; Tsunoda, M. Synthesis and properties of umbelliferone-nitroxide radical hybrid compounds as fluorescence and spin-label probes. Spectrochim. Acta Part A 2008, 70, 799-804.

16. Sato, S.; Tsunoda, M.; Suzuki, M.; Kutsuna, M.; Takido-uchi, K.; Shindo, M.; Mizuguchi, H.; Obara, H.; Ohya, H. Synthesis and spectral properties of polymethine-cyanine dye-nitroxide radical hybrid compounds for use as fluorescence probes to monitor reducing species and radicals. Spectrochim. Acta Part A 2009, 71, 2030-2039.

17. Ikeda, M.; Nagawa, H.; Suzuki, T.; Miyata, N. Novel bisbenzimide-nitroxides for nuclear redox imaging in living cells. Bioorg. Med. Chem. Lett. 2012, 22, 1949-1952.

18. $\pi$-Electron Magnetism: From Molecule to Magnetic Materials. Structure and Bonding; Rawson, J.M., Palacio, F., Veciana, J., Eds.; Springer Verlag: Berlin, Germany, 2001; Volume 100, pp. 93-128.

19. Hata, M.; Akutsu, H.; Yamada, J.-I.; Nakatsuji, S. N-Salicylideneamine derivatives with TEMPO substituents. Molecules 2004, 9, 746-756. 
20. Burroughes, J.H.; Bradley, D.D.C.; Brown, A.R.; Marks, R.N.; Mackay, K.; Friend, R.H.; Burn, P.L.; Holmes, A.B. Light-emitting diodes based on conjugated polymers. Nature 1990, 347, 539-541.

21. Goodson, T.; Li, W.; Gharavi, A.; Yu, L. Oligophenylenevinylenes for light-emitting diodes. Adv. Mater. 1997, 9, 639-643.

22. Müllen, K.; Wegner, G. Electronic Materials: The Oligomer Approach; Wiley-VCH: New York, NY, USA, 1998.

23. Gierschner, J.; Ehni, M.; Egelhaaf, H.-J.; Millian, B.; Beljonne, D.; Benmansour, H.; Bazan, G.C. Solid-state optical properties of linear polyconjugated molecules: $\pi$-Stack contra herringbone. J. Chem. Phys. 2005, 123, 144914.

24. Kraft, A.; Grimsdale, A.C.; Holmes, A.B. Elektrolumineszierende konjugierte polymere-polymere erstrahlen in neuem licht. Angew. Chem. 1998, 110, 416-443.

25. Kraft, A.; Grimsdale, A.C.; Holmes, A.B. Electroluminescent conjugated polymers-Seeing polymers in a new light. Angew. Chem. Int. Ed. Engl. 1998, 37, 402-428.

26. Mathy, A.; Ueberhofen, K.; Schenk, R.; Gregorius, H.; Garay, R.; Müllen, K.; Bubeck, C. Third-harmonic-generation spectroscopy of poly( $p$-phenylenevinylene): A comparison with oligomers and scaling laws for conjugated polymers. Phys. Rev. B 1996, 53, 4367-4375.

27. Gurge, R.M.; Hickl, M.; Krause, G.; Lahti, P.M.; Hu, B.; Yang, Z.; Karasz, F.E. Synthesis of a green-emitting alternating block copolymer. Polym. Adv. Technol. 1998, 9, 504-510.

28. Skotheim, T.A.; Reynolds, J.R. Handbook of Conducting Polymers, Part III: Properties and Characterization of Conducting Polymers; CRC Press: Boca Raton, FL, USA, 2007.

29. Strehmel, B.; Sarker, A.M.; Detert, H. The Influence of $\sigma$ and $\pi$ Acceptors on Two-Photon Absorption and Solvatochromism of Dipolar and Quadrupolar Unsaturated Organic Compounds. ChemPhysChem 2003, 4, 249-259.

30. Collette, J.C.; Harper, A.W. Properties and chemical environment effects of alkylamino styryl pyrazine two-photon fluorophores. Proc. SPIE 2003, 5212, 184-192.

31. Woo, H.Y.; Liu, B.; Kohler, B.; Korystov, D.; Mikhailovsky, A.; Bazan, G.C. Solvent Effects on the Two-Photon Absorption of Distyrylbenzene Chromophores. J. Am. Chem. Soc. 2005, 127, 14721-14729.

32. Czerney, P.; Grummt, U.-W. New near-infrared-absorbing acidochromic dyes and their application in sensor techniques. Sensor. Actuat. B.-Chem. 1997, 39, 395-400.

33. Schmitt, V.; Glang, S.; Preis, J.; Detert, H. Proton-Induced Multiple Changes of the Absorption and Fluorescence Spectra of Amino-Aza-Oligo(phenylenevinylene)s. Sens. Lett. 2008, 6, 524-530.

34. Lippert, E.; Lüder, W.; Moll, F.; Nägele, W.; Boos, H. Prigge, H.; Seybold-Blankenstein, I. Umwandlung von Elektronenanregungsenergie. Angew. Chem. 1961, 73, 695-706.

35. Rettig, W. Ladungstrennung in angeregten Zuständen entkoppelter Systeme-TICT-Verbindungen und Implikationen für die Entwicklung neuer Laserfarbstoffe sowie für den Primärprozeß von Sehvorgang und Photosynthese. Angew. Chem. 1986, 98, 969-986.

36. Rettig, W. Charge separation in excited states of decoupled systems-Tict compounds and implications regarding the development of new laser dyes and the primary process of vision and photosynthesis. Angew. Chem. Int. Ed. Engl. 1986, 25, 971-988. 
37. Dobkowski, J.; Michl, J.; Waluk, J. Electronic spectroscopy and photophysics of 2-( $N$-methyl- $N$ isopropylamino)-5-cyanopyridine and related compounds. Phys. Chem. Chem. Phys. 2003, 5, 1027-1031.

38. Nemkovich, N.A.; Detert, H.; Schmitt, V. Localized excitation effect on dipole moments of oligophenylenevinylenes in their excited Franck-Condon state. Chem. Phys. 2010, 378, 37-41.

39. Detert, H.; Sadovski, O.; Sugiono, E. Acidochromism of $\mathrm{C}_{2}$-symmetrical aza-analogues of 1,4-distyrylbenzene. J. Phys. Org. Chem. 2004, 17, 1046-1050.

40. Detert, H.; Sugiono, E. Bis(pyridylvinyl)diaminobenzenes: Synthesis, acidochromism and solvatochromism of the fluorescence. J. Lumin. 2005, 112, 372-376.

41. Hancock, J.M.; Jenekhe, S.A. Unusual protonation-induced continuous tunability of optical properties and electroluminescence of a $\pi$-conjugated heterocyclic oligomer. Macromolecules 2008, 41, 6864-6867.

42. Yamaguchi, Y.; Kobayashi, S.; Wakamiya, T.; Matsubara, Y.; Yoshida, Z.-I. Banana-shaped oligo(aryleneethynylene)s: Synthesis and light-emitting characteristics. Angew. Chem. Int. Ed. 2005, 44, 7040-7044.

43. Percino, M.J.; Chapela, V.M.; Sánchez, A.; Maldonado-Rivera, J.L. Condensation reactions of methylpyridines and aromatic aldehydesunder catalyst and solvent free conditions. Chem. Indian J. 2006, 3, 262-267.

44. Percino, M.J.; Chapela, V.M.; Salmón, M.; Toscano, R.A. Unexpected crystallization and X-ray crystal structure of racemic 1-phenyl-2-(4-pyridyl)ethanol intermediate. J. Chem. Crystallogr. 2000, 30, 385-388.

45. Percino, M.J.; Chapela, V.M.; Salmón, M.; Espinoza-Pérez, G.; Herrera, A.M.; Flores, A. X-ray crystal structure of 2-styrylpyridine. J. Chem. Crystallogr. 1997, 27, 549-552.

46. Chapela, V.M.; Percino, M.J.; Rodríguez-Barbarín, C. Crystal structure of 2,6-distyrylpyridine. J. Chem. Crystallogr. 2003, 33, 77-83.

47. Percino, M.J.; Chapela, V.M.; Montiel, L.-F.; Rodríguez-Barabrin, C. X-Ray crystal structures of a 1 -( $p$-fluorophenyl)-2-( $\alpha$-pyridyl)ethanol intermediate and the 1-( $p$-fluorophenyl)-2- $(\alpha-$ pyridyl)ethane dehydration compound obtained from the condensation reaction of 2-methylpyridine and $p$-fluorobenzaldehyde. Open Crystallogr. J. 2008, 1, 37-41.

48. Percino, M.J.; Chapela, V.M.; Montiel, L.-F.; Pérez-Gutierrez, E.; Maldonado, J.L. Spectroscopic characterization of halogen- and cyano-substituted pyridinevinylenes synthesized without catalyst or solvent. Chem. Pap. 2010, 64, 360-367.

49. Percino, M.J.; Chapela, V.M. Unexpected intermediate 1-phenyl-2-(4-pyridyl)ethanol isolated from benzaldehyde and 4-picoline condensation reaction. Res. Chem. Intermed. 2000, 26, 303-307.

50. Pérez-Gutierrez, E.; Percino, M.J.; Chapela, V.M.; Maldonado, J.L. Optical and morphological characterization by atomic force microscopy of luminescent 2-styrylpyridine derivative compounds with poly( $N$-vinylcarbazole) films. Thin Solid Films 2011, 519, 6015-6020.

51. Percino, M.J.; Chapela, V.M.; Urzua, O.; Montiel, L.-F.; Rodríguez-Barabrín, C. 1-( $p$-Fluorophenyl)-2-(2'-pyridyl)ethanol and 1-(p-Fluorophenyl)-2-(2'-pyridyl)ethene obtained from the condensation reaction of 2-picoline and $p$-fluorophenylaldehyde under catalyst- and solvent-free conditions. Res. Chem. Intermed. 2007, 33, 623-629. 
52. Castro, M.E.; Percino, M.J.; Chapela, V.M.; Cerón, M.; Soriano, G.; Melendez, F. Theoretical Study of the UV/Vis Absorption Spectra of Styrylpyridine Compounds Using TD-DFT Calculations. J. Mol. Model. 2013, 19, 2015-2026.

53. Percino, M.J.; Chapela, V.M.; Perez-Gutierrez, E.; Ceron, M.; Soriano, G. Synthesis, optical and spectroscopic characterization of substituted 3-phenyl-2-arylacrylonitriles. Chem. Pap. 2011, 65, 42-51.

54. Percino, M.J.; Chapela, V.M.; Cerón, M.; Soriano-Moro, G.; Castro, M.E. Synthesis and molecular structure of the 1-phenyl-2-(2-pyridyl)ethanol intermediate obtained from the condensation reaction of 2-picoline and benzaldehyde. Res. Chem. Intermed. 2013, doi:10.1007/s11164-013-141471-y.

55. Allen, F.H.; Kennard, O.; Watson, D.G.; Brammer, L.; Orpen, A.G.; Taylor, R. Tables of bond lengths determined by X-ray and neutron diffraction. Part 1. Bond lengths in organic compounds. J. Chem. Soc. Perkin Trans. 1987, 12, S1-S19.

56. Rintoul, L.; Micallef, A.S.; Bottle, S.E. The vibrational group frequency of the N-O• stretching band of nitroxide stable free radicals. Spectrochim. Acta Part A 2008, 70, 713-717.

57. Nakanishi, K.; Solomon P.H. Infrared Absorption Spectroscopy, 2nd ed.; Holden-Day Inc.: Oakland, CA, USA, 1977.

58. Williams, D.H.; Fleming, I. Spectroscopic Methods in Organic Chemistry, 3rd ed.; McGraw-Hill: Maidenhead, UK, 1980.

59. Daku, L.M.L.; Linares, J.; Boillot, M.-L. Ab Initio Static and Molecular Dynamics Study of 4-Styrylpyridine. ChemPhysChem 2007, 8, 1402-1416.

60. Daku, L.M. L.; Linares, J.; Boillot, M.-L. Ab initio static and molecular dynamics study of the absorption spectra of the 4-styrylpyridine photoswitch in its cis and trans forms. Phys. Chem. Chem. Phys. 2010, 12, 6107-6123.

61. Zhadanov, R.I.; Golubev, V.A.; Rozantsev, E.G. Synthesis and structure of 1-oxopiperidinium tribromides. Izv. Akad. Nauk SSSR. Ser. Khim. 1970, 1, 186-187.

62. Dane, E.L.; Maly, T.; Debelouchina, G.T.; Griffin, R.G.; Swager, T.M. Synthesis of a BDPA-TEMPO biradical. Org. Lett. 2009, 11, 1871-1874.

63. Sheldrick, G.M. SHELXTL/PC User Manual; Siemens Analytical X-ray Instruments Inc.: Madison, WI, USA, 1990.

Sample Availability: Samples of the compounds are available from the authors.

(C) 2015 by the authors; licensee MDPI, Basel, Switzerland. This article is an open access article distributed under the terms and conditions of the Creative Commons Attribution license (http://creativecommons.org/licenses/by/4.0/). 